\title{
ENTRE O LAgO E A HISTÓRIA: PEDRO CASALDÁligA E A CONSCIÊNCIA DA MISSÃO
}

\author{
Michael Jhonatan Sousa Santos \\ Mestre em Estudos de Linguagem pelo PPGEL/UFMT \\ Doutorando em Estudos Literários pelo PPGEL/UFMT \\ E-mail:michael.santos@pdl.ifmt.edu.br
}

Resumo: Neste artigo, analisamos a representação do espaço natural na poesia de Pedro Casaldáliga. Realizando um tipo de topoanálise, procura-se levantar às funções desempenhadas pelas imagens da natureza na obra do escritor e refletir acerca de como se traduz em poesia o contraste entre a exuberante natureza do nordeste de Mato Grosso e a opressão social que caracterizou sua colonização. Elabora-se, assim, uma reflexão acerca de como a missão de constituir uma sociedade mais justa estrutura a obra poética de Casaldáliga, em favor de uma historicidade, e a respeito de como essa consciência disputa com as imagens da natureza, que quando se harmonizam com o engajamento tendem ao lirismo.

Palavras-chave: Pedro Casaldáliga. Poesia. Natureza e cultura.

\section{INTRODUÇÃO}

A leitura da obra poética de Pedro Casaldáliga revela que tão recorrentes quanto os poemas que tematizam problemas sociais, concernentes ao modelo de ocupação e colonização da região nordeste de Mato Grosso, Brasil, são aqueles em que o poeta constrói espaços naturais e expressa sentimentos advindos da natureza. Por isso, "cultura", como uma referência àquilo define as sociedades humanas (WILLIANS, 2011), e "natureza" são o ponto inicial deste trabalho.

No prefácio ao livro Antologia retirante (1978, p 15), jogando com a constituição histórica e social do significado do termo "natureza", Casaldáliga afirma ser "naturalmente, retirante da Poesia hermética". Trata-se de um comentário do poeta a respeito do modo como, esteticamente, concebe e deseja sua poesia. Cultivada, mas natural, acerca dela, Casaldáliga ainda nos diz o seguinte:

Amigos, não busqueis nestes meus versos a Poesia profissional. Dou o verso, como davam seu leite as vacas branquinegras que meu pai ordenhava, de madrugada e ao entardecer; como dá o seu pregão o chico-preto de nosso quintal, atrás da catedral-barração de São Félix; como dá o meu povo retirante o seu olhar, sua prece, seu golpe rítmico de enxada, sua pancada libertadora no arame do Latifúndio; como dou a amargura, o sorriso, a mão estendida, o testemunho do que já vi, do 
que espero. Joan Maragall queria apenas "a Palavra Viva”. Eu só reconheço aquela Poesia em comunhão emocionada com a Terra, com o Homem, com o Céu. (1978, p. 15)

Inicialmente, observamos que o poeta estabelece uma relação de semelhança entre os recursos estéticos que emprega na construção de seus poemas e fenômenos da natureza e da cultura. Assim, é possível inferir que para Casaldáliga tais fenômenos representam, mais do que matéria para poesia, um modelo formal de versificação. Contudo, algumas questões se nos apresentaram, quando refletíamos sobre os elementos que agregavam valor estético às criações de Casaldáliga: para ele, a poesia surge de modo natural, no sentido de algo que é "espontâneo", ou a natureza é, de certo modo, poética? Ainda que haja nas palavras do poeta uma crítica explícita à poesia que se volta para ela mesma, para as sutilezas do seu fazer, sem preocupações com a representação social, "hermética", como não admitir um grau considerável de hermetismo, quando os seus versos captam metaforicamente e se assemelham, por exemplo, a fenômenos da natureza e a compreensão destes constitui o objetivo das ciências? Ou ainda, como a estrutura de seus versos transita da natureza para cultura, como se dá esse movimento do olhar?

No âmbito de valores, por assim dizer, semântico-existenciais, Casaldáliga faz de sua obra uma imagem da emoção que sente pela beleza que percebe na natureza e nos homens e de luta contra a opressão exercida pelos próprios homens, uns sobre outros, menos favorecidos. Por esse motivo, constitui um apelo no sentido do fim de situações de opressão e reflete o engajamento do poeta nas lutas sociais empreendidas pelos índios e posseiros da região de São Félix do Araguaia.

Frente a isso, neste artigo, buscamos analisar o espaço natural na poesia de Pedro Casaldáliga. Realizando um tipo de topoanálise, procura-se levantar às funções desempenhadas pelas imagens da natureza na obra do escritor e refletir acerca de como se traduz em poesia o contraste entre a exuberante natureza do norte de Mato Grosso e a violência que caracterizou sua colonização.

\section{ENTRE O LAGO E A HISTÓRIA}

$\mathrm{Na}$ poética de Casaldáliga, as imagens da natureza são bastante heterogêneas, cumprindo funções diversas, mesmo quando consideradas somente aquelas que surgem na condição de paisagem. Elas são desde a evidência e a denúncia de crimes (Versos Adversos, 
2006, p. 67) até a prática inútil da beleza (Antologia Retirante, 1978, p. 85). Isso porque constituem um de seus elementos fundamentais, à maneira de um "coração" num organismo, desempenhando função vital.

Para pensarmos nessas funções das imagens da natureza na obra de Casaldáliga, iniciemos com o poema "Beleza perfeita", publicado no livro Antologia retirante (1979, p. 43):

\section{BELEZA PERFEITA}

Quero escrever a alma desta hora,

Como quem prega na lapela de festa

a borboleta última

- creme, limão, canário -

que acaba de pulsar entre meus olhos

bêbados de formosura...

A beleza perfeita destas águas amigas;

a vida exuberante da floresta múltipla:

o sarã rasteiro chapinhando,

$\mathrm{o}$ alto louro moço,

a imbaúba-figueira de lapela virada ,

o vermelho estendido

e a taboca fiandeira

de filamentos amarelos e de lancetas verdes-claras.

Revoa um papagaio travesso de alegria.

Cruzamos ilhas, lagos, enseadas.

As nuvens lassas dão ao rio quieto

um tom de transida madrepérola.

E o sol de Mato Grosso faz-se tíbio

para não calcinar tanta beleza.

O barco pára. Falam os meninos

do tão falado amor.

e riem duas mocinhas morenas, na margem,

descalças, despenteadas,

pura beleza índia em bruto. 
Outra vez se adiou o casamento!

Ronca o motor de novo. A menina

de mil sangues cruzados

- Ásia, África, Europa: Ó América! -

me sorri com dentes espaçados

e umas tranças minúsculas,

emoldurada na luz,

pela janela aberta à flor do rio.

Depois, entre as páginas do livro

-a palavra e margem paralelas-

uma inhuma de peitilho branco

alça vôo, inefável, dessa areia

eriçada de um verde calafrio.

Dividido em quatro estrofes, respaldando-se numa demonstração/experienciação de sensibilidade para com o espaço natural, o poema mobiliza recursos da narração e da lírica.

Preliminarmente, destacamos que a noção de universo e microuniversos, reiterada nas imagens da terra e em suas metonímias, ao longo da obra de Casaldáliga (SOUZA, REIS, 2014), foi o que, primeiramente, despertou-nos para a ambiguidade do título do poema. Tal figura, usada como referência ao universo, aos vegetais e aos animais do nosso planeta, acrescentamos, pressupõe um Todo conectado - a ideia de um Ser supremo que está em todas as coisas e as movimenta num ciclo cósmico. Essa compreensão decorreu do qualificador "perfeita" e de sua projeção na tradição literária.

A busca pela perfeição, ou a "beleza perfeita", é um tema que, na literatura, recorrentemente, associa-se à frustração, à dor e à morte. Essa associação atravessou milênios. Nesse sentido, citamos o conto O retrato Oval ${ }^{1}$, de Edgar Alan Poe (1982). Nessa obra, o protagonista é um artista que pinta uma tela de sua esposa. Quando julga ter alcançado a perfeição, percebe que sua modelo está morta. Isso parece ocorrer porque a perfeição estaria além de toda possibilidade humana, por pressupor uma apreensão integral daquilo que visa retratar. A perfeição seria da ordem do divino.

${ }_{1}^{1}$ Pode ser citado, também, da obra Metamorfoses, de Ovídio, os versos 243 a 297 do Livro II, a história do artista Pigmalião e de Galatéia, sua escultura que ganhou vida. (BULFINCH, 2006, p. 72) 
No poema, na qualidade de espaço, as imagens da natureza dizem, assim, de um modelo de perfeição, buscado tanto no campo das relações sociais quanto na arte, apontando, em última instância, para a perfeição divina. A esse respeito, lembramos que a associação da noção de belo ao campo da arte é posterior ao século XVIII, antes disso, a beleza não era mencionada como algo produzível pelo homem (ABBAGNANO, 2007). Segundo a teoria do belo no platonismo, a beleza é o lugar de encontro do homem com substâncias ideais; a releitura dessa teoria pelo neoplatonismo ganhou corpulência teológica e mística porque as substâncias ideais de que falou Platão foram unificadas na ideia de Deus, ou Uno, do qual todas as coisas boas emanam e para o qual retornam (ABBAGNANO, 2007).

Comparando "Beleza perfeita" a outros poemas do escritor, verifica-se que constitui uma exceção ${ }^{2}$. Trata-se de um dos poucos textos em que Casaldáliga produz um eu lírico livre de angústias ou de preocupações sociais, no qual não é feita qualquer menção à violência ou à exploração do ser humano, no qual não há indício de dor ou sofrimento. Pelo contrário, o eu lírico contempla e reflete, de modo prazeroso, sobre o espaço natural que o envolve. Quando se refere à cultura indígena e à formação da América, não o faz em termos do processo de destruição cultural, dizimação de vidas humanas, animais e vegetais que representou a colonização portuguesa no Brasil. Mas, com leveza e graciosidade, o bispo-poeta aborda questões como o "amor", o "casamento", a natureza, a cultura e, principalmente, a possibilidade de a "beleza" interligar esses elementos. Não se trata de um alheamento às questões sociais e históricas, ou da recriação de um índio ideal, mas de uma opção artística, muitas vezes preterida. Opção esta sobre a qual doravante nos deteremos.

Esse processo de comparação permitiu-nos agrupar os textos poéticos de Casaldáliga, que versam sobre a natureza, na qualidade de paisagem, em três conjuntos, segundo a funcionalidade desempenhada pelas imagens do espaço natural.

O menor desses conjuntos abarca textos nos quais o eu poético contempla a natureza e esse ato não é interrompido por qualquer indício de dor ou sofrimento, assemelhando-se, nesse sentido, ao poema "Beleza perfeita". Nestes poemas, a contemplação do espaço natural e a reflexão acerca dele adquirem importância em si mesmos. Internamente ao conjunto, pudemos observar que uns se destacam em lirismo e conotação enquanto há outros que aglutinam imagens do espaço natural.

\footnotetext{
${ }^{2}$ Uma análise que incide especificamente sobre o poema "Beleza perfeita" pode ser acessada na dissertação Natureza e Cultura na poesia de Pedro Casaldáliga (SANTOS, 2016). Disponível em: http://www.ufmt.br/ppgel/index.php?option=com_content\&view=article\&id=93\&Itemid=304\&lang=pt-br
} 
“Criaturas Irmãs", terceira parte da obra Antologia retirante (1978), além de nos fornecer uma boa amostra desse conjunto, inicia-se com o poema "Plantei um jardim" (Antologia Retirante, 1978, p. 85), que citamos abaixo, a fim de ilustrar o grupo tratado:

\author{
Plantei um jardim. Cultivo flores \\ em vasos e em latas. \\ Pratico a beleza inutilmente.
}

Rego as folhas verdes e seus gritos efêmeros.

Protejo-as da ventania,

do sol calcinador. Dou, cada dia,

três ou quatro olhares protetores,

e surpreendo a Criação fazendo-se ...

Elas, nunca me disseram como sentem

este humano desvelo sem cobiças;

mas vivem, florescem, me acompanham;

atendem as visitas, gratamente,

como falando por mim, como dizendo-me;

circundam de paz o Araguaia,

e balizam de esperas, de perguntas,

de respostas, de cantos florescidos,

o horizonte longamente opaco.

Além de "gracioso", "suave" e "leve" são termos que qualificam, justamente, o poema acima transcrito. Considerando-se a potencialidade expressiva dos fonemas, é possível concluir que essas qualidades decorrem não apenas da temática amena, o "cultivo de flores", mas também da camada fônica, que suscita essas impressões. Nesse sentido, destacamos a ampla utilização de assonâncias nas vogais abertas /a/ e /e/. Ao longo do poema, /a/ apresenta 52 repetições, e /e/ 59; juntos totalizam um grupo de ocorrências 33\% maior do que o constituído pelos três outros fonemas vocálicos, que totalizam apenas 76 repetições. Aqueles fonemas, de acordo com Lemos Monteiro (1991), sugerem "sentimentos positivos" (p. 100), o que nos autoriza a relacioná-los às sensações de suavidade, leveza e, em última instância, de prazer e 
felicidade, no contexto do poema. Assim, o valor expressivo dos fonemas em questão evidencia-se pelo seu uso reiterado.

Nas duas primeiras estrofes, observamos que o "jardim" é apresentado como um lugar que pode ser habitado, visitado, amado, cuidado e cultivado. Ele constitui o "aqui" em que vive o eu lírico. Na terceira, por outro lado, há uma projeção do jardim sobre o entorno do Rio Araguaia. Trata-se de uma sobreposição do "aqui" sobre o "lá". Em outros termos, de um colocar o "aqui" em perspectiva. Indeterminação justificada pelo caráter metonímico desses lugares.

Em virtude disso, é possível depreender do poema uma categoria daquilo que Collot (2013) chama de "pensamento-paisagem": a superação da oposição entre natureza e cultura.

Nesse sentido, se, nos três primeiros versos, o poeta refere-se às plantas de "jardim", nos quatros últimos percebemos que essas plantas não se diferenciam daquelas que compõem as matas ciliares do Rio Araguaia. Essa relação de semelhança entre o "jardim" e a floresta constitui uma leitura possível em virtude da concordância do verbo "circundar", terceira estrofe, sexto verso, com o pronome "elas", que inicia a estrofe anterior e remete ao significante "flores". Este, por sua vez, funciona como uma metonímia de planta. Outro elemento que atesta tal leitura é a utilização do significante "Criação", na segunda estrofe, usado como referência ao "jardim", mas que conota também a ação divina de dar existência ao mundo na visão do cristianismo. Nisso verificamos o valor metonímico do "jardim”, que se apresenta conectado com o todo, que é a "Criação". Em virtude desse deslocamento do próximo ao distante, o poema sugere uma paisagem, sem, contudo, descrevê-la, fato que se explicita no último verso, quando o poeta mobiliza a imagem do "horizonte".

Assim, a semelhança entre o "jardim" e a floresta, o próximo e o distante, permite verificar que a natureza pode ser "cultivada", em outras palavras, que não se opõe à cultura, quando esta opera livre de "cobiças". Desse modo, o poema sugere que qualquer elemento da flora, cultivado ou espontaneamente gerado, é igualmente natureza, passível de ser visitado, habitado e amado. O que diferenciaria tais elementos entre si seria, nesse sentido, o modo como nos relacionamos com eles, se por "cobiça", se por afeto.

À ação humana que visa um contato afetivo homem-natureza, Casaldáliga chama prática “inútil da beleza”. O termo "inútil”, nesse caso, não possui valor pejorativo. Ao contrário, conota um interesse pela coisa em si, uma relação de afeto genuíno com a natureza, porque dela não espera uma contrapartida. Isso não significa que, ao longo da obra do poeta, os elementos da fauna e da flora sejam desprovidos de sua importância nutritiva para a vida humana, como se verifica em diversos poemas, como "Bananas", no qual é feita uma apologia ao consumo 
dessa fruta, exaltando suas propriedades: "Exuberantes ubres tropicais. / Gulodice de macacos. / Solução de emergência. Proletárias. Vitamina de pobre. [...] - Nossas bananas de cada dia, / nos dai hoje!"'(CASALDÁLIGA, 1978, p. 105).

Essa compreensão do que seja natureza, engendrada pelo poema, opõe-se fundamentalmente a um padrão de atitudes, vigente há ao menos um século, quando o assunto tratado é a proteção e o cuidado com o meio ambiente natural ou conservação da natureza. Sobre esse padrão, em Domesticando o mito da natureza selvagem, os antropólogos GómezPompa e Kaus (2000) explicam que visões tradicionais de conservação "afirmam que existe uma relação inversa entre as ações humanas e o bem-estar do meio ambiente natural” (p. 127). Dentro dessas perspectivas, a natureza é algo distante do homem e deve assim ser mantida. Tal posicionamento é errôneo, embora fundamente diversas políticas ambientais, de acordo com os autores citados.

Em nossa opinião, o fato de os impactos ambientais provocados pelo desmatamento urbano serem pouco abordados e estudados pelas diversas mídias e pela academia, respectivamente, se comparados àqueles que ocorrem em florestas e em outras áreas preservadas, somente atesta uma visão coletiva de que a fauna e a flora urbanos, quer de jardins, quer de quintais, não são natureza como o é a biodiversidade dos parques florestais. Mediante a esse processo, que em consonância com Raymond Williams (2011) podemos chamar 'abstração da natureza' a tudo aquilo que deriva da ação do homem sobre seu meio, a população das cidades pôde acompanhar, insensivelmente, a redução da flora urbana, a queda dasárvores de fundos de quintais. Nesse sentido, explica Williams (2011), é como se o ser humano fosse dotado de um toque profano e a natureza fosse tudo aquilo que permanece "imaculado" ou "tudo o que não fora tocado ou estragado pelo homem: a natureza como locais solitários, como o selvagem" (p. 103). Logo, não nos vemos destruindo a natureza quando resolvemos cortar uma árvore que cultivávamos como se fosse um pomar.

Ao projetar seu "jardim” no "horizonte” para o qual se esvai o Rio Araguaia, o eu lírico opõe-se latitudinalmente a esse modo de pensar a flora cultivada e de relacionamento com ela. Plantar um "jardim" pode ser conservar a natureza e se relacionar com ela de modo sensível. Dessa maneira, o poema diz do cuidado com uma natureza na qual o ser humano está integrado, por fazer parte da "Criação", de modo que, cuidar do meio ambiente natural, é também cuidar de si mesmo.

Esse conhecimento produzido pelo poema ressoa em outros campos do saber. Na área da ecologia histórica, segundo Philippe Descola (1997), desconstrói-se a imagem da Floresta 
Amazônica como um ecossistema formado sem interferência humana e afirma-se justamente o contrário, demonstrando impacto favorável da ação de populações indígenas sobre a floresta:

A abundância dos solos antropogênicos e sua associação com florestas de palmeiras ou de árvores frutíferas silvestres sugerem que a distribuição dos tipos de floresta e de vegetação na região resulta, em parte, de vários milénios de ocupação por populações cuja presença recorrente nos mesmos sítios transformou profundamente a paisagem vegetal. As próprias concentrações artificiais de certos recursos vegetais teriam influído na distribuição e na demografia das espécies animais que deles se alimentavam, de tal modo que a natureza amazônica é, na verdade, muito pouco natural, podendo ser considerada, ao contrário, o produto cultural de uma manipulação muito antiga da fauna e da flora. Embora sejam invisíveis para um observador inexperiente, as consequências desta antropização estão longe de ser irrelevantes, sobretudo no que diz respeito à taxa de biodiversidade, mais elevada nas porções de floresta antropogênicas do que nas porções de floresta não modificadas pelo homem. (p. 243-4)

A seleta de poemas, aqui representados pelo "Plantei um jardim", e as relações de intertextualidade entre este e o "Beleza perfeita", sugerem uma imagem-síntese para nomear o conjunto em questão: "natureza cultivada em poemas".

No segundo grupamento, reunimos aqueles poemas cujas imagens do espaço natural compõemse, internamente, em função de um sentimento de incômodo infligido aos seres poéticos pelo capitalismo e suas práticas, tornando-se fundamentais para o efeito de crítica social que esses textos produzem. Esse tipo de funcionalidade do espaço natural pode ser observada quando as imagens da natureza são mobilizadas para criticar e denunciar as injustiças nas relações sociais, a distribuição desigual de itens necessários à vida humana digna, ou ainda, as questões relativas à dominação e exploração da natureza e o modo como isso é sentido por diversos grupos sociais. Não se trata da temática dos poemas em si, mas do modo como as imagens do espaço natural se articulam, em função de uma crítica ao capitalismo e seus efeitos perniciosos, não figurando exclusivamente como adorno, plano de fundo ou elemento mobilizado a fim de ser rompido para que um terceiro ganhe ênfase.

Compõe esse grupo, dentre outros, o belo "Hai kai da lua ocupada" (Águas do tempo, 1977, p. 40):

\author{
Cada vez que olho a lua \\ sinto o pé de Amstrong \\ em meus olhos.
}


Na obra Pedro Casaldáliga e a poética da emancipação, Marinete Souza e Célia Reis (2014) analisam o poema acima demonstrando seu caráter crítico e irônico. As autoras destacam a particularização de sentido do termo "lua", através da forma nominal do verbo ocupar, que, no caso, indica uma privatização deste satélite natural. Tal ocupação, no contexto do poema, acrescentam, evidencia a oposição entre valores culturais diversos: "os de conquista (com referência específica aos Estados Unidos) e os de liberdade no convívio com a Natureza (os do povo da região do Araguaia)" (p. 66).Ademais, situam-no em sua emergência histórica, fundindo texto e contexto numa leitura dialética, conforme orientação de Antonio Candido (2006). Desse modo, as estudiosas demonstram que a paisagem lunar, no poema, propicia uma reflexão acerca da "corrida para a lua", disputada entre a União Soviética e os Estados Unidos no período da Guerra Fria e sobre o papel das mídias de comunicação em massa nesse processo. Partindo desse pressuposto, verificamos que o poema em questão se inscreve no conjunto de que tratamos porque a "lua", enquanto elemento da paisagem natural, não se separa do efeito de crítica ao paradigma capitalista de relação entre homem e natureza que o texto engendra.

Embora haja uma quase ruptura de sentido do primeiro para o segundo verso, ela não se concretiza, porque não há um isolamento da carga semântica da palavra "lua", que, a nosso ver, sugere, no poema, uma contemplação prazerosa do espaço. Em consonância com isso, Marinete Souza e Célia Reis (2014) afirmam que o verso indica a "frequência do ato, hábito cultural (ritual de muitas etnias) que revela o poder da lua iluminando a noturnidade da terra com seus encantadores e misteriosos espetáculos cromáticos” (p. 65).

No verso segundo, através do substantivo próprio “Armstrong”, é apresentado o produto da chegada do homem à "lua". Introduz-se no poema, por meio deste verso, o sentimento de angústia. Tal sentimento, porém, não decorre apenas da ação de "Armstrong", mas também, do fato de essa ação ser precedida por uma sensação de prazer e implicar na sua suspensão. Jogando com a transitividade do verbo "sentir", a imagem que se conclui no pronome possessivo "meus" aplicado ao órgão da visão, já no último verso, é uma sinestesia. Assim, a ação do astronauta sobre a "lua" é vivida pelo eu poético como um contato físico incômodo. Compõe-se uma figura a partir da qual se sugere, tomando a "lua" como metonímia da natureza, a não separação entre o que seria o corpo do eu poético e o meio ambiente natural que o envolve, apontando para a não separação entre sujeito e objeto e para uma identidade última entre o homem e o mundo. Assim, a quase ruptura que mencionamos não se concretiza, porque, figurativamente, o homem e a "lua" são um só. A sugestão de ruptura serve, então, para confrontar situações, temporalidades e significações diversas da natureza, provenientes de culturas diferentes. Como o efeito produzido por esse confronto é de crítica ao paradigma de 
dominação do homem sobre a natureza, cunhado pelo capitalismo, o espaço natural constituise em função desse efeito, tornando-se inseparável dele.

Outros poemas apresentam esse nível de integração entre as imagens do espaço natural e as formas usadas para criticar os comportamentos sociais e políticos engendrados pelo capitalismo, dentre os quais citamos, ainda, da obra Águas do tempo (1977), o "Embiruçu" (p. 28) e “As águas da barragem" (p. 46).

Dentro desse grupo, mesmo tendo em vista tal estruturação comum, verificamos um alto grau de heterogeneidade entre os poemas, o que nos obrigou a formar o terceiro conjunto.

Ocorreu que as imagens do espaço natural tendem a escapar dessa relação intrínseca com o que temos chamado função de "crítica aos mecanismos políticos e econômicos de opressão a diversos grupos sociais brasileiros", mas que pode ser entendido, de modo mais amplo, como formas do engajamento, e assumir, por assim dizer, o protagonismo dos poemas. Em virtude disso, aparecem deslocadas ou contrastando com essas formas, produzindo efeitos diversos.

Se "Beleza perfeita", por suas qualidades, pode ser entendido como um dos textos que melhor representa o primeiro conjunto, é também representativo do terceiro o texto "Junto ao vosso canto", que transcrevemos abaixo, tentando manter a mesma diagramação usada na obra Versos adversos (2006, p. 13), a fim de que observemos o contraste entre as imagens da natureza e as formas do engajamento, de que tratamos:

Meu silêncio seja
meu poema, irmãos,
junto ao vosso canto.
Seja minha ausência
como um voo de garças
abraçando a tarde,
nesse voo de garças
que invadiu o dia
com o vosso canto.
Velhos de esperança
- tantas luas cheias,
tantas noites foscas -
eu e o Araguaia
já nos conhecemos,
rios de um só rio,
ajeitando o curso
entre Deus e o Povo.
Junto ao vosso canto,
boca coletiva,
seja meu silêncio
posto de joelhos
uma escuta nova.

Meu silêncio seja meu poema, irmãos,

Seja minha ausência como um voo de garças abraçando a tarde, nesse voo de garças que invadiu o dia Velhos de esperança - tantas luas cheias, tantas noites foscas eu e o Araguaia já nos conhecemos, rios de um só rio, ajeitando o curso Junto ao vosso canto, seja meu silêncio uma escuta nova.
Quero ouvir o Povo!

Quero ouvir o grito das crianças mortas comandando a vida. Quero ouvir as covas dos peões de trecho soletrando vivos os perdidos nomes. Quero ouvir os pobres num clamor de enxadas conquistando a terra. Quero ouvir a dança das aldeias novas nas antigas flautas acordando o mundo.

Toda a minha sede, cuia de silêncio, beba em vosso canto o Araguaia novo, luta nas enchentes, festa no banzeiro, Povo, Povo, Povo! 
Composto de sete estrofes, organizadas em duas colunas, o poema "Junto ao vosso canto" (2006, p. 13) está inteiramente metrificado em redondilhas menores. Movimentando o significante "silêncio" e remetendo-se à escritura poética, reformula um modelo de presença que passa a se concretizar, também, a partir da inexistência de som, da ausência física, da "escuta" dos "mortos".

$\mathrm{Na}$ segunda estrofe, evoca-se um relacionamento afetivo com a natureza, marcado pela contemplação prazerosa do espaço, como um parâmetro de comparação. Na seguinte, esse relacionamento é colocado numa linha temporal, indicada pelos ciclos lunares e pelo termo "velhos", elementos que visam dar noção da intimidade existente entre o eu lírico e

o espaço natural, personificado, que o envolve, compreensão essa que requer uma leitura metonímica da palavra “Araguaia”. Até a quarta estrofe, não é possível indicar qualquer contraste entre as imagens do espaço natural e as formas do engajamento, manifestas na constante menção ao "coletivo" e a uma luta que se perpetua para além da presença corporale da vida orgânica de cada homem.

Porém, na estrofe quinta e sexta, esse contraste aparece nítido, o que decorre, também, da estruturação em colunas na qual o poema é apresentado. A partir daí, embora desloque imagens como as antíteses vida/morte, novo/antigo, recursos de repetição como a anáfora, e a insistência em sons nasalizados, decorrentes do gerúndio, as estrofes resultam referenciais. Como resultado dessa disjunção entre as imagens do espaço natural e as formas do engajamento, a primeira coluna ganha em lirismo e a segunda, em detrimento desta qualidade, em historicidade. Não é, assim, demasiado dizer que a quinta e a sexta estrofes apresentam um estilo diferente das demais.

Nessas estrofes, ao reiterar "seu desejo de ouvir os mortos", o eu lírico promove um clamor por justiça social. Na septilha terminal, quando mobiliza o termo "sede", o poema intertextualiza o "Sermão da montanha", segundo São Mateus, capítulo 5, verso 6, no que tange às bem-aventuranças: "Bem-aventurados os que têm [...] sede de justiça, porque serão saciados". Tal compreensão, contudo, não reconcilia as imagens da natureza e a forma dada pelo engajamento, na quinta e na sexta estrofe, dificultando uma leitura em que estas sejam tangenciadas por aquelas. 


\section{CONSIDERAÇÕES FINAIS}

A disjunção entre as imagens da natureza na qualidade de espaço percebido, de belezas naturais, e as formas criadas pelo engajamento é uma estrutura comum à obra de Casaldáliga. Estes são, com efeito, textos divididos entre uma experiência sensível, afetiva e, às vezes, estética do meio ambiente natural e o engajamento literário que anima a poética dele. Motivados pela intertextualidade que se estabelece entre essa estrutura e o poema "Aldeia Tapirapé" (Antologia Retirante, data, p 195), no qual o poeta se refere a tal separação como que a justificando, apresentando-lhe os motivos, chamamos o grupo de textos em que esse fenômeno ocorre de "entre o Lago e a História". Em virtude disso, vejamos o referido poema:

Do outro lado um pássaro responde ao meu silêncio,

confirmando a mútua profecia.

(Os pássaros são livres quando os homens o são.) E um

peixe tucunaré, como uma rubrica,

salta, rompendo a água,

selada pela luz e a treva

unidas em penumbra de anistia.

Eu sou o mundo inteiro.

Todos os tempos são, comigo, esta hora de ocaso, sobre o lago.

Duas canoas se abrem, em ângulo e signo, ao

Lago e a História.

Cantídio dava, esta noite, suas pistas principais.

Como seu povo era, no Princípio.

Como chegou o tori com suas ofertas [...] 
O poema "Aldeia Tapirapé" compõe-se de doze estrofes irregulares, das quais transcrevemos as três primeiras e os versos iniciais da quarta.

Na primeira estrofe, percebemos que o eu lírico narra uma experiência de contemplação e vivência da natureza na qualidade de espaço. O elemento textual que possibilita essa afirmação é a locução adverbial de lugar "do outro lado". No verso primeiro, é feita uma menção ao som e, nos dois finais, a "água" é caracterizada, sugerindo a percepção de espaço natural pela visão. O surgimento da paisagem se dá, assim, pela sinestesia. A pergunta que fazemos é, portanto, como a sensação de espacialidade pode surgir tão forte, tão bela, já na primeira estrofe, com base nesses tão poucos elementos materiais do texto?

Os dois elementos textuais que dizem do espaço são aplicados de modo vago. A locução “do outro lado" poderia referir-se à "aldeia". Quanto ao termo "água", só na segunda estrofe percebemos que é referência a um "lago", quando, então, ressignificando-o, podemos propor uma leitura por metonímia, quando se pode pensar em outra margem. Por conseguinte, esses elementos não explicam a sensação de espacialidade provocada pela estrofe.

Tuan (1983) afirma que o "espaço é liberdade" (p. 3). Talvez a sensação de espacialidade que a primeira estrofe suscita decorra, em parte, de o poeta relacionar imagens da natureza, tanto da fauna quanto da atmosfera, ao significante "livres", fazendo-as, por essa relação simples, sugerir uma paisagem, mesmo sem descrevê- la totalmente.

A percepção, como propõe Michel Collot (2013), "não somente reúne os dados dos sentidos, mas integra o que não lhe é dado diretamente: por exemplo, a face oculta dos objetos" (p. 24). Nessa perspectiva, aquilo que o texto apresenta como visível sugere uma espacialidade não dita, logo, invisível. De tal maneira, Casaldáliga consegue criar o espaço caracterizando-o minimamente.

Para que tal explicação seja cabível em termos epistemológicos, não se pode perder de vista o conhecimento produzido pelo poema "Beleza perfeita" de que os elementos da experiência sensível transitam para a escritura poética: “"Quero escrever a alma desta hora". Em outros termos, segundo Collot (2013, p. 46), não se pode ignorar que a expressão poética não se diferencia da experiência sensível da qual procede. Nesse sentido, a percepção, como a escritura poética, 
não nos dá a ver a extensão de uma região [de um país] se não ocultando outras regiões do olhar, das quais, no entanto, deixa-nos pressentir a presença, fazendo com que o nosso aqui se comunique virtualmente com o próprio mundo inteiro, que é o horizonte dos horizontes, e como tal, inesgotável. (COLLOT, 2013, p. 24)

Desse modo, mesmo que não ofereça um processo de descrição minucioso, como o realizado no poema "Beleza Perfeita", o poeta deixa-nos entrever, no efeito que o espaço provoca no eu lírico, uma paisagem.

Esse efeito, estabelecido desde os versos iniciais, diz respeito a uma compreensão que a paisagem, segundo Collot (2013), pode suscitar em nós, e que, acrescenta ele, os poetas, desde o romantismo, buscaram apresentar. Nesse contexto, a paisagem é aquilo que

transgride a oposição entre sujeito e objeto, o individual e o universal; embora possa assumir todos os valores da afetividade mais íntima, a convergência dos olhares faz dessa afetividade um lugar comum para mim e para os outros (p. 27)

Os “olhares” são aqui o do poeta, o do eu poético e o do leitor. A paisagem, por seu turno, é tanto o próprio poema quanto pode se referir a um espaço referencial, que ele visa à recriação e universalização. Nessa perspectiva, verifica-se que, a partir de uma compreensão ampla do que seja "liberdade", o eu poético propõe uma semelhança entre si e o meio ambiente que o envolve "(Os pássaros são livres quando os homens o são)".

Esse ponto de similitude marcado pelo significante "livres" prenuncia um momento de indistinção maior entre o homem (o eu) e o mundo, o qual aparece nítido no verso "Eu sou o mundo inteiro“. Este apresenta uma subjetividade que, frente à paisagem, flagra-se, surpreendentemente, constituída pelo "outro", que é "o mundo inteiro". O verso também se refere a um interior que se vê constituído pelo exterior. Isso não indica uma fusão do sujeito com o seu meio, já que a própria paisagem supõe um distanciamento entre esses elementos. É certo, contudo, que se refere ao engajamento presente na obra de Casaldáliga. Assim, as imagens da natureza, engendradas pelo poema, são também de engajamento.

A partir desses versos, o poema apresenta características semelhantes às destacadas na segunda coluna de "Junto ao vosso". Em outros termos, ocorre a ruptura entre as imagens da natureza e as formas do engajamento que distingue o 
grupo de poemas dos quais estamos a tratar. Tal ruptura, porém, não se dá sem aviso ou explicações, como ocorre em diversos textos. Esse aviso, tanto ao leitor quanto ao eu lírico, vem da paisagem, silencioso, mas se faz ouvir no canto dos pássaros, em forma de texto ou de pintura, como sugere o termo "rubrica", na primeira estrofe. Trata- se de um indicativo de mudança no modo de escrever, suscitado por uma mudança no assunto.

Uma das premissas sobre as quais Collot (2013) estrutura seus estudos sobre a paisagem é a de que mais do que fazer pensar e ter ideias a possibilidade dessas ideias "está inscrita na própria percepção da paisagem" (p. 17). O teórico explica que esse modo de "pensar" não decorre do interior do sujeito, determinando-lhe a existência, totalmente, nem lhe é exterior apenas.

Em nosso ponto de vista, a experiência vivida pelo eu poético, tal como apresentada no dístico "Duas canoas se abrem, em ângulo e signo,/ ao Lago e a História", refere-se, justamente, a esse momento de encontro entre um ser e o mundo, sendo este reconhecido como significante que faz aquele pensar. A relação que a estrofe em questão mantém com as que a sucedem deixa implícita a opção pela "História", feita pelo eu lírico, no poema em questão.

Tais considerações não apenas visam ressaltar a importância do dístico em questão para a compreensão do poema. Constituem, na verdade, uma opção de leitura para todo um conjunto de poemas produzidos por Casaldáliga. Permitem verificar que a reflexão produzida sobre as paisagens naturais e culturais na obra poética propõe a superação de dicotomias nas quais se fundam comportamentos sociais de exploração e destruição do homem e dos espaços que habita e dos quais depende para sobreviver. Em todo caso, elabora-se uma reflexão acerca de como a missão de constituir uma sociedade mais justa estrutura a obra poética de Casaldáliga, muitas vezes em favor da referencialidade e em detrimento do poético.

\section{BIBLIOGRAFIA}

ABBAGNANO, N. Dicionário de Filosofia.Trad. BOSI, A. BENEDETTI, J. 5. ed. São Paulo: Martins Fontes, 2007.

BACHELARD, G. A poética do espaço.Trad. Antonio de Pádua Danesi. São Paulo: Martins Fonte, 2003. 
BOFF, L. As quatro ecologias: ambiental, política e social, mental e integral. Rio de Janeiro: Mar de ideias, 2012.

BOURG, D. (org.) Os Sentimentos da Natureza. Lisboa: Instituto Piaget, 1993. BOSI, A. O Ser e o Tempo da Poesia. São Paulo: Cultrix, Ed. USP, 1977.

BULFINCH, T. Mitologia: história de deuses e heróis. Trad. DAVID, J. Rio de Janeiro: Ediouro, 2006, p. 72 - 74.

CANDIDO, A. Literatura e Sociedade. 9ed. Ouro Sobre o Azul: Rio de Janeiro, 2006. O estudo analítico do poema. São Paulo: Humanitas Publicações/ FFLCH/USP, 1996.

CASALDÁliGA, P. Antologia Retirante. Rio de Janeiro: Civilização Brasileira, 1978. Cantigas Menores. Goiânia: Projornal, 1979. . A cuia de Gedeão: poemas e autos sacramentais sertanejos.

Rio de Janeiro: Petrópolis, 1982.

Orações da caminhada. Campinas: Verus Editora, 2005. Águas do tempo. Cuiabá: Fundação Cultural de Mato Grosso, 1989.

Versos adversos. São Paulo: Fundação Perseu Abrano, 2006. e VIGIL, J. M. Espiritualidad de La Liberación. Quito: Verbo Divino, Quito 1992. Na procura do Reino: antologia de textos. Trad. Antônio Carlos Moura. São Paulo: FTD, 1988.

COHEN, Jean. Nível Fônico: a versificação. In: COHEN, J. Estrutura e linguagem poética. Trad. Álvaro Lorencini e Ane Armichand. São Paulo: Cultrix/Edusp, 1974, (p. 46 - 86).

COLlOT, M. Poética e filosofia da paisagem. Trad. Ida Alves... [et al.]. Rio de Janeiro: Editora Oficina Raquel, 2013.

CHKLOVSKI, V. A arte como procedimento. In: EIKHENBAUM et ali. Teoria da Literatura: formalistas russos. Porto Alegre: O Globo, 1976, (p. 39 - 56).

GÓMEZ-POMPA, A. KAUS, A. Domesticando o mito da natureza selvagem. In: DIEGUES, A. (org.) Etnoconservação: novos rumos para a conservação da natureza. São Paulo: Hucitec/Annablume/Nupaub-USP, 2000 (p. 125-148).

LINS, O. Lima Barreto e o espaço romanesco. São Paulo: Ática, 1976. MAGALHÃES, H.

G. D. História da Literatura de Mato Grosso. Séc.XX. Cuiabá: UNICEM, 2001.

MARTINS, N. S. Introdução à Estilística: a expressividade na Língua Portuguesa.

4 ed. São Paulo: Editora da Universidade de São Paulo, 2008.

MOISÉS, M. Dicionário de termos literários. 12. ed. São Paulo: Cultrix, 2004.

MONTEIRO, J. L. A estilística. São Paulo: Ática, 1991.

PAZ, O. O Arco e a Lira. Trad. Olga Savary, Rio de Janeiro: Nova Fronteira, 1982.

Signos em Rotação. Trad. $2^{\mathrm{a}}, 1976$.

PHILIPPE, D. Ecologia e Cosmologia. In: CASTRO, E. \& PINTON, F. (orgs.) Faces do trópico úmido: conceitos e questões sobre desenvolvimento e meio ambiente. Belém: Ed. Cejup/UFPA/NAEA, 1997 (p. 243-261). 
POE, E. A. Ficção completa, poesia e ensaio. Trad. Oscar Mendes. Rio de Janeiro: Nova Aguilar, 1982.

SOUZA, M. F. L. REIS, C. M. R. Pedro Casaldáliga e a poética da emancipação. Cuiabá: EdUFMT, 2014.

TUAN, Yi-Fu. Perspectiva experiencial. In: Espaço e Lugar: a perspectiva da experiência. Tradução de Lívia Oliveira. São Paulo: DIFEL, 1983, (p. 9 - 21).

THOMAS, K. O homem e mundo natural: mudanças de atitude em relação às plantas e aos animais. Trad. FILHO, J. R. M. São Paulo: Companhia da Letras, 2010.

WILLIANS, R. Cultura e Materialismo. Trad. André Glaset. São Paulo: Editora Unesp, 2011. 